\title{
Investment Recovery: Understanding The Book Value Vs. Fair Market Value Of An Asset
}

Robert Slater, University of North Florida, USA

Vincent Shea, Saint John's University, USA

\begin{abstract}
This case is based on a real life conversation between CPA Dave Richards and business owner John Stevenson. John has run across a situation with his business in which he has a discrepancy between what he feels an asset is worth and with what a company has the asset valued on the books. The manager of the company does not want to sell an unused asset because he does not want the loss on the equipment to impact his division's performance this period. Students get to listen along as Dave and John discuss the issues.

This case introduces students to the accounting for capital assets, sales of used equipment and the tax consequences of selling equipment. Students are introduced to John Stevenson and Dave Richards as they discuss an issue John Stevenson has come across in his investment recovery business. Students are exposed to capital asset accounting and valuation from both a Generally Accepted Accounting Principles view and from a general businessman's view. The case also covers an issue of goal conflict and goal congruence with respect to the company who currently owns the asset. This case is targeted for students in an MBA course who are not accounting majors. The case may be used as an in class discussion mechanism or assigned as a take home project. The case can be discussed fully within a one hour class if students have pre-prepared for the case. Students should expect to spend about 1 hours of preparation time outside of class.
\end{abstract}

Keywords: Investment Recovery; Asset Disposal; Depreciation; Book Value

\section{CASE}

$\mathrm{n}$ an upscale neighborhood, John Stevenson was watering grass when he noticed his neighbor Dave Richards riding a bicycle down the street. John stopped watering the grass and walked out to the street, hailing Dave with a wave of his arm. Dave did not see John at first and almost hit him with his bike. John jumped back onto the grass as Dave grabbed the front and back brakes of the bike simultaneously and skidded to a stop right where John had been previously standing.

Dave grabbed the headphones from his ears and reached down to turn off his MP3 player. He looked at John and said, "Sorry, I did not see you there. I get a bit zoned out while riding and listening to my CPA exam review tapes."

John quickly replied, "No, I am sorry. I almost made you crash!” Then, realizing what Dave had just said about his audio selection, John asked, "Haven’t you been a CPA for over 15 years?"

"Yes, I have been, um - I am a CPA," replied Dave. Realizing why he was being asked this question, Dave straightened up on his bike and said, "I just really enjoy hearing the accounting rules while I ride. It relaxes me."

“Ooookay," said John, wondering if he really wanted to ask Dave his question now. 
After a few seconds of silence, Dave said inquisitively, "Sooooo-."

John interrupted, “I wasn’t judging you, really."

Puzzled, Dave replied, "What?" He then peered at John and continued, “Anyway, why did you stop me?"

"Oh, oh yeah," John replied. "I meant to call you at work today and I forgot. I need some help in dealing with an accountant at a company I am doing business with."

"Well, what do you have in mind when you say 'help in dealing with'?" Dave joked. "I am not going to beat anyone up! We CPAs have a code of conduct you know."

"That's for sure!" John thought to himself silently, and then replied, "No, no, no. I am just having a problem with the way they keep their books. I am trying to sell a piece of their equipment, and this guy's convoluted ideas about accounting are really getting in the way. He just doesn't understand business! I think he is doing some funny accounting, maybe even something fraudulent. I need you to tell me how I can straighten him out and make this sale."

"Well, I would have to hear more details before I could determine if I could be of any help to you," Dave replied. "I am in the middle of my ride, and then I have dinner plans tonight. Can I come by your office in the morning so we can go over the details?"

“Would you rather I come to your office?” John asked.

Dave replied, "Nah, if I come to your office, I can write the mileage off as a business expense. If I am just commuting to work, that's not deductible."

"Our offices are less than a mile from our neighborhood. Does it really make a difference?" John queried.

"Every little bit helps, every little bit," said Dave. "I'll be there at 9:00am."

At 8:59am the next morning, Dave Richards stood outside the door of John's company staring at his watch. As he read the sign on the door, he realized that John's company was called "Investment Recovery Services," and Dave thought to himself, "'I.R.S.', how cool!" Looking back down at the digital numbers on his wrist, Dave saw the numbers change to 9:00. Dave walked through the door smiling and thinking, "Right on time, every time!" He then turned his attention to the receptionist's desk. There was a person at the desk busy writing, but all Dave could see was the top of a head. In his best professional voice, Dave said, "Hello, I am Dave Richards, CPA. I'm here to see John Stevenson."

“Hey Dave! It’s good to see you again”, replied the receptionist.

At that moment, Dave realized that the receptionist was John's wife, Susie. Dave knew Susie from around the neighborhood. Politely, but less formally, Dave said, "Susie, I didn't know you worked." Dave paused, realizing that he didn't want to end his sentence with such an awkward statement, and added, "Um - worked here."

Susie replied, "I don't usually work here, but Janet is out sick on maternity leave. You know what John says, 'Business never stops.', so I'm here filling in for her. It's been kind of fun working a bit and John likes it 'cause I'm not down at the mall spending what he's making." She looked down at the phone in front of her, noticing the lights indicating which phone lines were occupied. She smiled back up at Dave, "John is on the phone right now, but I know he's expecting you. You can go to his office now. I'm sure he will get off the phone when he sees you."

Dave hesitated but followed Susie's instructions and walked down the hall to John's office. John was sitting in a large brown leather chair at an even larger wooden desk, which was covered end to end with papers. On the wall behind John was a sign with the phrase "Business Never Stops." John was leaning forward on the desk with a scowl on his face as he listened to the caller on the other end of the line. 
John did not notice Dave walk in as he began his response. "I don't care that your buddy bought the machine from you directly. We have a contract. Your company and Investment Recovery Services entered into a contract that states that we get $15 \%$ of the sale price for each asset sold on that plant's premises." John paused as he listened to the other end of the line impatiently and then, obviously interrupting the caller, he continued his rant.

"Once we signed that contract, it doesn't matter who finds the buyer: you, me, or the tooth fairy! Investment Recovery Services gets $15 \%$ of the sale price of each asset sold from that site. I put considerable resources into this job. I had guys out at your factory for three weeks inventorying every asset on that site. My people have been making cold calls, doing research, and trying to find buyers for those assets. Either have your assistant send us a check for $15 \%$ of the sales price with a copy of the buyer's check, or your next call will be from my attorney. I don't work for free you know!"

Just then, John noticed David standing in his doorway. Dave awkwardly looked away at first, a bit nervous about having eavesdropped on the conversation. John flashed a quick grin toward Dave, letting him know that the rant he had heard was just an act. John then motioned for Dave to sit down in front of the big wooden desk as he continued to listen to the caller's response. He spoke into the phone "Okay, I'll look forward to seeing the check when it gets here." Hanging up, he looked up and said, "Dave, good to see you! Sorry about that."

"No problem," replied Dave. "Was that the problem customer?"

"No, that's a new customer," replied John. "We seem to go through the same problem with most new customers. A lot of them hire us to sell assets they are not using. Then someone at the company tries to cherry pick the easy sales away from us. I have to fight that behavior up front. My contracts are pretty good, but my attorney is even better. I don't know why they would expect me to work for free."

“So you don’t actually buy and then sell stuff; you just sell it. Is that correct?” asked Dave.

"That is correct," replied John. "We work as an agent most of the time. We will inventory, photo, and catalog all the assets of a plant that are no longer in use and then find buyers for the assets. We then get a percentage of all sales during the period of our contract. Sometimes companies just hire us to do the inventory and cataloging, but that is on a cost plus basis. This guy wanted the best of both worlds. He wanted us to do the inventory and cataloging for free, and then he tries to sell the assets without paying us."

"So the problem -," Dave began.

John interrupted, his voice a bit agitated, "The problem is that I've paid my guys a boatload of money to do the preliminary work, and this guy isn't going to steal sales from me!"

"I was trying to ask you what the problem was that you wanted my help with," Dave clarified.

"Oh, yeah," John said, "that is a different client and a different problem."

Dave said, "Alright, why don't we go over the specifics of that situation?"

"Let me find my notes on this one," John said as he shuffled some papers across his desk. "You are not going to believe this one. I have an accountant that doesn't know spit from Shinola!"

Dave replied, "I really think that phrase is-,"

Before Dave could finish his correction, John stopped him, saying, "I KNOW what the correct phrase is, but I promised Susie that every time I cuss, I would put 5 dollars in the cuss jar." John pointed to a glass jar sitting behind him, filled to the rim with $\$ 5$ bills. "That's the third time I've filled that...that..." As he spoke, he pulled a 5dollar bill from his pocket, as if contemplating whether a colorfully honest descriptor of the jar was worth it. He tucked the bill back into his shirt pocket and continued his rant, "That darn jar! So I've started making up my own phrases." 
Dave attempted to get the conversation back on track, "So this accountant doesn't know his stuff?"

"No, no, he doesn't." John said. "He's crazy. They have a machine they bought for 6 million and he is telling me that they paid 10 million. I've even seen the invoice, and the cost of the equipment was 6 million dollars." yours?"

Dave said, "Wait, back up a second. Can you give me a little background on the situation? Is this a client of

"Yes," John replied. "I've contracted with Wright Way Manufacturing to sell a large generator. I found a buyer who is willing to pay 2.5 million for the thing, but now the operations manager doesn't want to sell it. He says he doesn't want his division to incur a loss on the sale. He would rather keep the asset and continue to depreciate it year to year."

"You mean he wants more money for it?" asked Dave.

"Well, that really isn't his big problem," replied John. "His big concern is the loss on the sale. He doesn't want it on his books. This is where I have a problem with this guy's business knowledge. They want to pass up 2.5 million dollars cash because they say they are going to lose 3.4 million on the sale. That's crazy. They only paid 6 million for the generator." machine?"

"Wait a second, John," Dave said, looking a bit lost in the numbers. "How long have they had this

"Five years," John replied.

Dave continued, "And how much did they pay for it?"

"Well, that's the crazy part," John responded, "they paid 6 million for the machine, but they are saying it cost 10 million dollars. Anyway, 10 million is the amount they have on their books for it. I am telling you, there is something odd about the accounting for this. I've been in business for 20 years and I've never seen such stupidity. This may even be fraudulent, I tell you! They are trying to tell me stuff like the reinforcements they made to their plant to handle this machine are part of the cost of the machine. Even worse, they have added the costs of their employees' salaries from test runs of the machine. Can you believe that? This has to be bad accounting!"

“No, I don’t think it is.” responded Dave. "Are they currently using this machine?"

John replied, "Well, they haven't used it in over a year. They currently have two of these at the same plant. Demand for the product was way less than expected. They only run one of these machines at a time now. If the other machine goes down, they can use this one. Upper management wants to try to pull the capital out of the machine for another product line that is doing very well."

Dave said to John, "Can you ask them to email you a copy of the capitalization worksheet for the generator?"

“What's that?” John asked.

Dave replied, "It's a breakdown of all the items they included in the cost of the machine."

"I'll have them email that over to me. Can you wait for a few minutes?" said John.

"Sure," said Dave, as he thought to himself, "Time is money, and the more time I am working for you, the more money I am making!" 
John picked up the phone and called the accountant at Wright Way Manufacturing. As Dave looked around the room, John began talking to the person on the other end of the call.

"This is John from Investment Recovery Services. Can you send me a copy of the -," John paused, cupped his hand over the phone and looked at Dave and asked, "What was it?"

"It is a capitalization worksheet for the generator," responded Dave. to me?"

"Did you hear that?" John asked. "I need the capitalization worksheet for that generator. Can you email that

Within a few minutes, the computer on John's desk let out an audible "Ding," and John opened the email and printed the worksheet.

"Is this what you needed?" John asked Dave as he handed him the worksheet.

“That's it. Perfect!” Dave replied, visibly brightening as he reviewed the document.

\begin{tabular}{|c|c|c|}
\hline \multicolumn{3}{|c|}{$\begin{array}{c}\text { Generator Capitalization Worksheet } \\
\text { Wright Way Manufacturing }\end{array}$} \\
\hline Initial purchase price of the machine w/taxes & $\$$ & $6,000,000$ \\
\hline Cost to ship the machine from the manufacturer in China & $\$$ & 900,000 \\
\hline Insurance on the machine in shipment & $\$$ & 300,000 \\
\hline Electrical wiring changes to the plant to support machine & $\$$ & 300,000 \\
\hline Building modifications needed to support the equipment weight & $\$$ & $2,000,000$ \\
\hline Labor and supplies to install the machine & $\$$ & 400,000 \\
\hline Labor and supplies used to test the machine before production & $\$$ & 100,000 \\
\hline Total Capitalized Cost of Machine & $\$$ & $10,000,000$ \\
\hline
\end{tabular}

Dave took a few minutes to look over the capitalization worksheet, then eyed John and said, "These numbers look okay, John.”

“That doesn't make sense!" replied John. "How can they expect another company to pay them for their inflated value of the machine? I mean, why should my buyer have to deal with the costs of modifications they made to their buildings?"

"They don't expect someone to pay them those costs. That's just the price at which they put the machine on the books," said Dave.

"But that's not the cost of the machine!" John repeated.

Dave thought about the situation for a few seconds and then said, "John, I think what we have here is a translation issue. We are really dealing with two different business languages."

Defensively, John said, "Two different languages! You sound just as crazy as they do."

"Let me explain," said Dave. "In your business, you are worried only about the relevant facts of selling a used piece of equipment. The buyer is either going to buy a new machine at fair market value or a used machine at some fraction of the new machine cost."

“Correct," John replied.

"Well," Dave began, "when a company buys a machine and they are using Generally Accepted Accounting Principles, they put the machine 'on the books' as we say, for the purchase price of the machine, plus all relevant costs to get the machine in position and condition for use." 
John interrupted, "But what do those costs have to do with the fair value of the machine now?"

“They don't —," began Dave.

"Then why are they including these costs as a loss now? "I don't care about these silly accounting rules!" retorted John. "They really shouldn't come into play in this deal. The buyer is willing to give them 2.5 million dollars for this machine and all they are worried about is some mythical loss on their books. They have already spent that money. The money is gone, and they are not going to get it back."

\section{ASSIGNMENT}

It's now time for you to take the role of CPA Dave Richards. Using your business knowledge and accounting skills, advise John Stevenson on the accounting treatment for capitalizing assets. You should also advise him on how he can convince Write Way Manufacturing to sell this piece of equipment. Do your best to answer each of the following questions.

\section{CASE QUESTIONS}

1. What costs do you think Wright Way Manufacturing should have included in the cost of the asset?

2. Where could we find guidance on how to account for capital assets?

3. John seems to think that the amount paid for the machine itself is all that should matter in valuing the asset for sale. Is John correct? Why would we have a difference between the book value of the asset valued using Generally Accepted Accounting Principles and the current market value of the asset?

4. What does the accumulated depreciation represent for the business?

5. According to the accounting standards, how should we treat an asset that is no longer in service?

6. If John can convince Wright Way Manufacturing to sell the asset and take the loss, what are the tax ramifications for Wright Way Manufacturing?

7. The manager at Wright Way Manufacturing said that he does not want to sell the asset and incur the loss right now. Is this what is best for the company? Discuss in terms of goal conflict and goal congruence.

\section{AUTHOR INFORMATION}

Robert D. Slater, Ph.D., CPA is an assistant professor of accounting at the University of North Florida. He received his Bachelor of Science, Master of Accountancy, and Ph.D. in business from the University of South Florida. Prior to his life in academia, he was a financial manager and network manager for a regional law firm in Tampa, Florida. His area of research and teaching specializes in accounting information systems. He has published in the Journal of Accountancy and presented his research at several national conferences. He is an active member of the American Accounting Association's Information Systems section. E-mail: robert.slater@unf.edu (Corresponding author)

Vincent Shea is an Assistant Professor of Accounting at St John's University in Queens, NY. He received his $\mathrm{Ph} . \mathrm{D}$. from Kent State University and is a CPA in New York and Florida. His current research and teaching areas are managerial accounting and accounting information systems. E-mail: sheaiiv@ stjohns.edu

\section{REFERENCES}

1. Peterson, R.H. (2002). Accounting for Fixed Assets. New York: J. Wiley.

2. $\quad$ http://aaahq.org/ascLogin.cfm; http://aaahq.org/FASB/Access.cfm

3. http://accounting-financial-tax.com/2009/08/definition-of-assets-fasb-concept-statement-6/ 


\section{INSTRUCTOR NOTES}

\section{Case Description}

This case introduces students to the accounting for capital assets, sales of used equipment, and the tax consequences of selling equipment. Students are introduced to John Stevenson and Dave Richards as they discuss an issue John Stevenson has come across in his investment recovery business. Students are exposed to capital asset accounting and valuation from the perspectives of both Generally Accepted Accounting Principles and a general businessman. The case also covers an issue of goal conflict and goal congruence with respect to the company who currently owns the asset. This case is targeted to students in an MBA course who are not accounting majors. The case may be used as an in-class discussion mechanism or assigned as a take home project. The case can be discussed fully within a one-hour class if students have pre-read the case. Students should expect to spend about one hour of preparation time outside of class.

\section{Case Questions}

1. What costs do you think Wright Way Manufacturing should have included in the cost of the asset?

Under Generally Accepted Accounting Principles, firms must record all costs related to the acquisition of the asset. Acquisition cost may include the original price paid for the asset, setup cost, installation cost, and any amount paid for shipping the asset to the purchaser. For Wright Way Manufacturing, this cost includes:

\section{XYZ Machine Capitalization Worksheet Wright Way Manufacturing Machine XYZ}

Initial purchase price of the machine w/taxes

Cost to ship the machine from the manufacturer in China

Insurance on the machine in shipment

Electrical wiring changes to the plant to support machine

Building modifications needed to support the equipment weight

Labor and supplies to install the machine

Labor and supplies used to test the machine before production

Total Capitalized Cost of Machine

\begin{tabular}{lr}
$\$$ & $6,000,000$ \\
$\$$ & 900,000 \\
$\$$ & 300,000 \\
$\$$ & 300,000 \\
$\$$ & $2,000,000$ \\
$\$$ & 400,000 \\
$\$$ & 100,000 \\
$\$$ & $\mathbf{1 0 , 0 0 0 , 0 0 0}$ \\
\hline
\end{tabular}

This capitalized cost will be used to calculate the annual depreciation cost for Wright Way Manufacturing.

2. Where could we find guidance on how to account for capital assets?

The Financial Accounting Standards Board, Accounting Standards Codification, provides guidance on fixed asset accounting. Access for this resource is free for both faculty and students. Login for the resource may be found at http://aaahq.org/ascLogin.cfm. Your school may need to first register for Faculty/Student Access. (http://aaahq.org/FASB/Access.cfm).

The Financial Accounting Standards Board also has concept statements that may be helpful for students. FASB Concept Statement 6 contains the definition of an asset and discusses the costs of assets (http://accountingfinancial-tax.com/2009/08/definition-of-assets-fasb-concept-statement-6/).

A discussion on depreciation methods and the matching principle may be found in the textbook Accounting for Fixed Assets (Peterson, R.H., 2002).Accounting for Fixed Assets. New York: J. Wiley.

3. John seems to think that the amount paid for the machine itself is all that should matter in valuing the asset for sale. Is John correct? Why would we have a difference between the book value of the asset valued using Generally Accepted Accounting Principles and the current market value of the asset? 
Wright Way Manufacturing is accounting for the purchase of the asset using Generally Accepted Accounting principles (GAAP). The concept behind the accounting for assets under GAAP is the matching concept, requiring us to recognize in our financial statements our expenses in the period in which the expenses were incurred. In capitalizing assets, companies try to reflect the fact that the money spent to acquire the assets and ensure that they are in a good condition for use will benefit the company long term. Thus, all these costs are included in the company's costs basis in the equipment and the company then selects a depreciation method to allocate the costs of the asset over its useful life. The main assumption with GAAP accounting is that the asset will remain in use during its expected life. The book value of an asset was never designed to reflect the current value of an asset. Once an asset is no longer in service, the company should write the asset down to the expected salvageable value.

On the other hand, John is worried about what an outside company would be willing to pay for the asset in its current condition. The costs paid by Wright Way Manufacturing to deliver the machine to their location and get the machine running add no value to the machine for an outside company. John is correct that the accounting book value means nothing when trying to sell the asset to an outside company.

\section{What does the accumulated depreciation represent for the business?}

Depreciation refers to the annual allocation of the cost of the asset over the period for which the asset is used. As time passes, firms depreciate the fixed asset in order to match the expense for the period of use. This amount is subtracted from the original acquisition cost of the asset to determine its current book value. All of this depreciation is collected in the accumulated depreciation account and remains on the financial statements until the firm disposes of the fixed asset.

Accumulated depreciation is important to the firm because the balance may indicate that the current year's depreciation has not yet been made. Since depreciation is an expense that lowers the operating income, it directly lowers the firm's tax liability. In addition, when the asset is sold, the accumulated depreciation is subtracted from the original acquisition cost to determine its current book value. The difference between the current book value and the amount received for the disposal of the asset is the asset's gain or loss. Any gain or loss received will directly affect the firm's tax liability.

5. According to the accounting standards, how should Wright Way Manufacturing treat an asset that is no longer in service?

If the asset is considered obsolete or no longer in use, the firm must write the asset down to the current market value of the asset. They would incur a loss on the difference between the current market value of the asset and the current book value of the asset.

6. If John can convince Wright Way Manufacturing to sell the asset and take the loss, what are the tax ramifications for Wright Way Manufacturing?

In order for John to determine the tax ramifications for the disposal of the fixed asset, he must first calculate its current book value. Book value is the difference between the asset's original acquisition cost, including all set-up and delivery costs, as mentioned in question one, and the accumulated depreciation collected over the life of the asset. Under US GAAP, firms may choose how to depreciate the asset. For example, one asset may use the straight-line method, while a different asset uses an accelerated method. The straight-line method assigns depreciation cost evenly over the life of the asset. The accelerated method allocates greater amounts of depreciation in the early years and smaller amounts near the end of the asset's life. Thus, the choice of depreciation method greatly affects the book value of the fixed asset.

The difference between the book value and the amount received at the time of disposal is a gain or loss. All gains are taxable at the firm's corporate rate, thus increasing the firm's tax liability. A loss could potentially lower the firm's tax liability, assuming it has income for the period. 
While the manager at Wright Way Manufacturing does not want to sell the machine and incur a loss in the current period, the loss on the sale of the equipment can benefit the company's cash flow in this period if they have positive taxable income.

7. The manager at Wright Way Manufacturing said that he does not want to sell the asset and incur the loss right now. Is this what is best for the company? Discuss in terms of goal conflict and goal congruence.

It appears that the manager is more worried about his departmental operations than the firm's operations as a whole. While the loss could look bad for his division, the fact that the asset is not currently in service means that the company should write the asset down to the current market value as soon as the asset is removed from operations. By continuing to hold the asset as if it were in service and continuing to depreciate the asset, the company is violating Generally Accepted Accounting Principles.

In this situation, we have what is considered a goal conflict, as the manager of Wright Way Manufacturing is more worried about what is good for his division's performance measures and not necessarily what is best for the company overall. The best course of action is to sell the asset and use the loss to offset some of the net income of the company for tax purposes. The manager of Wright Way Manufacturing needs to make a business case to his superiors that selling the asset makes sense from a cash flow standpoint. 


\section{NOTES}

